\title{
Patents versus transplants
}

SiR - In 1989, Gluckman and colleagues reported that haematopoietic stem cells from umbilical-cord blood of a neonate could be used as an alternative to bone marrow to engraft the donor's HLA-identical sibling who had Fanconi's anaemia. Seven years later, this patient is alive and apparently cured. Since 1989, it has become clear that cord blood can be used to treat patients in need of a bone-marrow transplantation.

The use of cord-blood cells has several advantages, including a higher concentration of immature progenitors leading to better engraftment and reduced immune reactivity. This allows successful transplants in the absence of a donor matched at all 6 HLA loci. More than 200 allogeneic cordblood transplants have been carried out, and autologous cord-blood cells have been used for gene therapy. Programmes of cord-blood banking have been established for family and unrelated transplants worldwide.

The technical, scientific, clinical and ethical aspects of the use of cord-blood stem-cells have been considered at a number of national and international meetings, and papers have been published in the scientific literature. These topics are the subject of continuing attention and evaluation by standing committees of the World Marrow Donor Association, the Immunobiology Working Party of the European Group for Blood and Marrow Transplantation, the Eurocord Transplant group and similar programmes in the United States.

It has recently been drawn to our attention that the clinical use of cord-blood stem cells, for all purposes, is the subject of a patent which is being actively disputed in the United States, which has been approved in Europe and which is being applied for in Japan. The holders of these patents presumably intend to exploit the use of cord-blood stem cells for commercial purposes and to oppose their use by transplanters unwilling to pay the patent fees. If these patents are enforced, the use of cord-blood cells for transplantation will not conform with the resolution of the International Society of Transplantation which establishes the basic principle that no part of the human body should be commercialized and that donation of organs or cells should be free and anonymous. For this reason, Eurocord has decided to oppose this patent.

The signatories of this letter believe that all procedures involving the transplantation of human organs, including haematopoietic stem cells, should be carried out only in an orthodox clinical setting where commercial considerations do not apply. Blood and organs are freely donated and there is an implicit agreement within the health-care community that they should not be used for the benefit of financial speculators. We con- demn any attempt to patent a nonpharmacological method of using this or any other haematopoietic stem-cell source for treating patients with haematological diseases and we recommend that clinicians and scientists dissociate themselves from patents of this type, whether they have already been granted or are only in the application stage.

\section{E. Gluckman*}

Hôpital St Louis,

1 Avenue Claude Vellefaux,

75010 Paris, France

e-mail: eliane.gluckman@chu-stlouis.fr

R. O'Reilly, Bone Marrow Transplant Service, Memorial Sloan-Kettering Cancer Center, New York J. Wagner, Pediatric Bone Marrow Transplant Program, University of Minnesota, Minneapolis; P. Rubinstein, New York Cord Blood Bank

* On behalf of J. Goldman, J. J. Van Rood, J. Dausset \& A. Gratwohl of the board of the European Blood and Marrow Society, the Eurocord transplant group, France Greffe de Moelle \& the board of the French Society of Bone Marrow Transplantation.

\section{Passive voice}

SIR - I am an academically trained linguist ( $\mathrm{PhD}$, University of Chicago). I have spent 14 years teaching English composition and linguistics in various universities, where I have taught graduate seminars on the structure and process of written language, and 15 more as a professional writer. I am not a regular reader of your publication; my brother, who is, showed me Simon Leather's letter, which purports to make "the case for the passive voice" (Nature 381, 467; 1996).

About all that I can say with certainty regarding the passive voice is that it omits the performer of the action, for reasons that may be contextual (the reader already knows who or what performed the action, so mentioning the agent is redundant); rhetorical (either the agent is unknown or irrelevant, or the writer wishes to conceal his/her/its identity); structural (the writer wishes to keep sentence-topic consistent from one sentence to the next); or cultural (as in scientific writing, where use of the passive, rigidly enforced by senior members of the community, serves as a sign of in-group membership).

Leather goes far beyond these simple truths, with absolutely no scientific data. Where are the quantitative stylistic analyses, where is the behavioural or psycholinguistic research to support his statements that " $[t]$ he use of the passive voice encourages disciplined writing" (indeed, "tenses must be used correctly" in all writing); that "using the active voice encourages possessiveness in the results and/or work;" that "the active voice [has a] tendency to foster colloquialisms;" that "the use of the active voice... leads to an unwillingness to see [the author's] results contradicted" and to "the fabrication of results"? I know of no such research. I strongly doubt that it exists.

I consider Leather's letter an outrageous display of scientific hypocrisy. He makes dogmatic pronouncements on a subject he knows nothing about. It's as if I, armed only with my tenth-grade biology course, were to undertake to prove the superiority of mammals over reptiles, on the grounds that the former are cuddly and smart, whereas the latter are slimy and stupid.

Leather should practise what he preaches: of the 18 transitive sentences in his letter, only four were in the passive.

Alan M. Perlman

Kraft Foods, Inc.,

Northfield, Illinois 60093, USA

\section{Public confidence}

SIR - Eugene Wong opens his Commentary article, "An economic case for basic research" (Nature 381, 187-188; 1996), with two statements that he puts forward as uncontested and deeply troubling facts.

It is simply not true, in the United States at least, that basic research is being pressured downwards in favour of more applied work. In fact, the sitting US Congress is strongly on record as favouring basic research. Second, Wong cites no evidence for his stated "change in the public perception of the benefits of basic research". The evidence of which I am aware, drawn from many years of National Science Board public opinion polls (Science \& Engineering Indicators - 1996) and current-year surveys in California, Florida and Texas commissioned by Research!America, tells the opposite story. For many years, at least 70 per cent of Americans of 18 years of age or older have said that they agree that "even if it brings no immediate benefits, basic science research which advances the frontiers of knowledge is necessary and should be supported by the Federal Government".

It is time for the research community to stop building a case based on overcoming presumed negatives and instead to build on the overwhelmingly positive regard in which the nonscientific public holds research, researchers and the institutions that house research.

Our rallying cry should be our pride in working in the public's interest; our strategies should include public outreach energized by a commitment to accessibility and accountability to a public that maintains a strong conviction that basic research is an essential investment in everyone's future.

\section{Mary Woolley}

(President)

Research!America,

1522 King Street,

Alexandria, Virginia 22314, USA 